\title{
Physicochemical and microbiological characteristics of minimally processed 'Champagne' oranges (Citrus reticulata $\times$ Citrus sinensis) in different packgings
}

\author{
Características físico-químicas e microbiológicas de laranjas 'Champagne’ (Citrus reticulata x Citrus sinensis) \\ minimamente processadas em diferentes embalagens
}

\author{
Juliana da Silva AGOSTINI ${ }^{1 *}$, Silvana de Paula Quintão SCALON ${ }^{2}$, Kesia Esther da SILVA ${ }^{3}$, \\ Fernando Freitas de LIMA³, Ana Paula Esteves GOMES ${ }^{3}$, Michelle Mesquita LEITE ${ }^{3}$
}

\begin{abstract}
The objective of this study was to investigate the influence of the level of minimal processing and modified atmosphere on the quality of 'Champagne' orange stored under refrigeration. The fruits were subjected to the following processing: a) whole fruit without flavedo; b) whole fruit without flavedo and albedo; and c) segmented into wedges and packed as follows: uncoated packaging (control); polyethylene film; PVC film; gelatin-based edible films (3\%); and polyesthyrene translucent plastic container with a lid. The minimally processed oranges were stored at $5 \pm 1{ }^{\circ} \mathrm{C}$ for 8 days and were subjected to physicochemical and microbiological analyses every two days. Greater weight loss occurred in fruits without flavedo and segmented, uncoated, and coated with the edible gelatin film During storage, there was a slight increase in Total Soluble Solids (TSS) for the treatments with greater weight loss and reduction in acidity and ascorbic acid, regardless of the packaging type. The microbial counts did not exceed the acceptable limits in the treatments; however, higher counts were observed at the end of storage. The minimally processed fruit packed in lidded polystyrene containers and polyethylene and PVC films kept their overall fresh visual appearance with a few physicochemical and microbiological changes up to the $8^{\text {th }}$ day of storage.
\end{abstract}

Keywords: citrus; minimal processing; conservation.

\section{Resumo}

Objetivou-se com este trabalho determinar a influência do nível de processamento mínimo e atmosfera modificada na qualidade de laranja 'Champagne' minimamente processada armazenada sob refrigeração. Laranjas submetidas aos seguintes processos: a) remoção do albedo; b) remoção do albedo e flavedo; c) segmentada em gomos, foram acondicionadas em embalagem sem revestimento (controle), com filme de polietileno, com filme de $\mathrm{PVC}$, com revestimento comestível de gelatina a 3\% e em pote plástico com tampa de poliestireno. O armazenamento dos frutos foi realizado a $5 \pm 1{ }^{\circ} \mathrm{C}$ por oito dias, sendo submetidos a análises físico-químicas e microbiológicas a cada dois dias. A maior perda de massa ocorreu em frutos sem flavedo e segmentados, sem revestimento e com película de gelatina. À medida que avançou o período de armazenamento, observou-se ligeira elevação no teor de SST para os tratamentos com maior perda de massa e redução da acidez e ácido ascórbico, sem efeito da embalagem. As contagens microbianas não ultrapassaram os limites preconizados em nenhum tratamento, entretanto, maiores contagens foram verificadas no final do armazenamento. As frutas minimamente processadas embaladas em potes de poliestireno com tampa, filmes de polietileno e PVC mantiveram boa aparência com poucas modificações nas características físico-químicas e microbiológicas até o $8^{\circ}$ dia de armazenamento.

Palavras-chave: citros; processamento mínimo; conservação.

\section{Introduction}

People have tried to eat more healthily including more fruits and vegetables in their diet. However, the time available for food preparation is short due to the hectic lifestyle people lead today. Accordingly, minimum processing, which is defined by Lima et al. (2005) as the operation that removes the inedible parts, dividing the product into smaller sizes for immediate consumption or preparation maintaining its freshness, quality, and sanity, arises as a good alternative.

In the case of oranges, minimal processing is very relevant since the fresh market is often limited by the inconvenience of peeling, especially due to the release of essential oils (GROPPO et al., 2009). The fact that oranges have specific physiological (non-climacteric) and morphological (structure into wedges) characteristics and are chilling-tolerant make them suitable for MPP (minimally processedproduct) processing operations in order to be more stable during storage (PLAZA et al., 2011; DONADON et al., 2004). This stability is due to the respiration rate of citrus fruits, which, when peeled, have the same respiration rate of the intact fruit after a few hours of processing due to the low production of ethylene. Even so,

\section{Received 20/5/2012}

Accepted 29/10/2012 (005681)

Institute of Health Sciences, Federal University of Mato Grosso - UFMT, Rua Alexandre Ferronato, 1200, Reserva 35, Setor Industrial, CEP 78550-000, Sinop, MT, Brazil, e-mail: juagostini@yahoo.com.br

2 Postgraduation Program in Agronomy, Federal University of Grande Dourados - UFGD, Dourados, MS, Brazil

${ }^{3}$ University Center of Grande Dourados - UNIGRAN, Dourados, MS, Brasil

${ }^{*}$ Corresponding author 
the operations involved in the processing of fruits always reduce their shelf life since the exudates from cutting are a favorable environment for the growth of fungi and bacteria (JACOMINO; ARRUDA; MOREIRA, 2005).

As a result of rough handling, these products' microbiota may have increased, changed or even contaminated with pathogen micro-organisms. Among the micro-organisms found in MPPs, are yeasts, total coliforms, fecal coliforms, molds, and mesophilic bacteria (NEGUYEN-THE; CARLIN, 1994). Therefore, it is necessary to combine controlling methods to minimize undesirable metabolic reactions that lead to deterioration and affect the characteristics and quality of MPPs. Thus, it is important to highlight that cooling, humidity control, addition of chemicals, and packaging in modified atmosphere have been frequently used to preserve the quality of these products increasing their shelf life (ARAÚJO; CHITARRA, 2005)

Modified atmospheres (MA), i.e., elevated concentrations of carbon dioxide and reduced levels of oxygen and ethylene, can be useful supplements to provide optimum temperature and relative humidity in maintaining the quality of fresh fruits and vegetables after harvest. Packaging fresh produce in polymeric films can result in a commodity-generated MA (KADER et al., 1989). Therefore, MA can be achieved in individual packages and edible coatings. such as gelatin, is interesting since it minimizes the physiological and biochemical process changes in minimally processed products and reduces contamination and proliferation of microorganisms delaying senescence.

Some national and international studies have investigated the MPP changes undergone by citrus fruits such as orange 'Valencia' (PLAZA et al., 2011), 'Felgueira' orange (ROCHA et al., 1995), 'Pera' orange (DONADON et al., 2004; LEME et al., 2007; ARRUDA, 2008, 2011; GROPPO et al., 2009), 'Salustiana' orange (PRETEL et al., 1998), tangerines (TIBOLA et al., 2006; PINTO; VILAS BOAS; DAMIANI, 2007; DEL-VALLE et al., 2009), Murcott 'Murcott' (KLUGE et al., 2003), and lemon (ARTÉSHERNÁNDES; RIVERA-CABRERA; KADER, 2007). However, 'Champagne' orange, also known as 'Cristal' and 'Champagne' mandarin, has not been studied yet. Therefore, this study aimed to evaluate the effect of different processing and passive modified atmosphere of minimally processed 'Champagne' oranges by means of physicochemical and microbiological analysis.

\section{Materials and methods}

'Champagne' oranges at the mature stage (50-75\% yellow skin) were manually harvested on a farm in the city of Amambaí (MS), located on the geographical coordinates of $23^{\circ} 02^{\prime} 32.67^{\prime \prime}$ $\mathrm{S}$ and $55^{\circ} 12^{\prime} 48.78^{\prime \prime} \mathrm{W}$. After being placed in plastic boxes, the fruits were quickly transported in refrigerated vehicles to the Food Science laboratory of the University Center of Grande Dourados to conduct experiments. The fruits that did not meet the maturity standards as well as those with signs of mechanical damage or pathological changes were discarded.

The oranges were selected, washed with detergent to remove dirt, immersed in a $200 \mathrm{mg} . \mathrm{L}^{-1}$ chloride solution for 10 minutes, and refrigerated for 12 hours at $5{ }^{\circ} \mathrm{C}$. After this period, they were subjected to the following processing preparation steps: a) whole fruit without albedo; b) whole fruit without albedo and flavedo; c) segmented into wedges. All fruits that were destined for processing, without albedo and flavedo, and cut into segments were subjected to hydrothermal treatment, which cons a) uncoated expanded polystyrene (EPS) trays (control); b) EPS tray covered by gelatin-based edible film (3\%); c) EPS tray covered by PVC stretch film $(9 \mu \mathrm{m})$; d) EPS tray covered by polyethylene film $(60 \mu \mathrm{m}) ; \mathrm{e})$ and polyesthyrene translucent plastic container with a lid.

For the preparation of the gelatin-based edible film, the following procedure was taken: water was added to gelatin, and the solution was heated to $70{ }^{\circ} \mathrm{C}$ under stirring until complete hydration. This mixture was cooled down to $30^{\circ} \mathrm{C}$, and then the fruits were dipped in this mixture for one minute, left to dry on metal screen drying trays, and placed on polystyrene trays.

All of these processing steps were performed in a room at $20^{\circ} \mathrm{C}$ on properly cleaned counters and all laboratory operators wore protective clothing (masks, gloves, caps, and aprons). The oranges were stored at $5{ }^{\circ} \mathrm{C}$ for 8 days, and every two days the samples of were removed from storage and analyzed for the following parameters: weight loss $\mathrm{pH}$, titratable acidity (TA), total soluble solids (TSS); vitamin C content (mg/100 g), total sugars (\%), and microbiology (psychrotrophic bacteria, yeasts and molds, and total coliforms and fecal coliforms).

The weight loss was determined by weighing the fruits in a semi-analytical balance, and the results expressed in percentage considering the difference between the initial weight of the trays containing the fruit stored and that obtained at each time interval of the experiments.

To evaluate the physical and chemical parameters, the fruits were removed from the trays and juice was extracted. The titratable acidity (TA) was determined by acid-base titration, the total soluble solids ( $\left.{ }^{\circ} \mathrm{Brix}\right)$ and $\mathrm{pH}$ were determined by direct reading of homogenized juice using an Abbe refractometer and a $\mathrm{pH}$ meter calibrated at $\mathrm{pH} 7.0$ and 4.0, respectively, and total sugars were determined by the Lane Eynon method (INSTITUTO..., 2005). Ascorbic acid (AA) was determined by the 2,6-dichloroindophenol titrimetic method (ASSOCIATION..., 1997).

The microbiological analysis for psychrotrophic bacteria, fungi, and yeast followed the methodology described by Silva et al. (2007). For the count of total coliforms and fecal coliforms, the PetrifilmTM EC plates (3 M Company, St. Paul, MN, USA) were inoculated with $1.0 \mathrm{~mL}$ aliquots of different dilutions of the juice extracted from the minimally processed oranges. The colonies were then counted and the results expressed in $\mathrm{CFU} / \mathrm{g}$. This experiment was arranged in a completely randomized factorial design, $5 \times 5$ factorial scheme, with five types of packaging (control, PVC coating, polyethylene coating, polystyrene container, and gelatin-based edible film $3 \%$ ) and five storage periods $(0,2,4,6$, and 8 days) for each of the three following types of orange processing and four replications.

From the results of the analysis of variance (F test), the interaction between the factors was subjected to regression 
analysis. For the cases in which there were no significant models or good curve fitting, the values were represented by points only.

\section{Results and discussion}

There was an interaction effect of time and packaging on weight loss of minimally processed 'Champagne' oranges (Figure 1). A linear increase in weight loss with increasing storage time was observed, especially for the minimally processed uncoated oranges (control) and those coated with the edible gelatin (3\%) film. It is worth noting that the fruits with gelatin-based edible coating had a greater weight loss than that of the control fruits. Since the gelatin coating is a hydrocolloid which retains moisture during the process of gel formation, it is possible that additional water loss does not result from the water itself, but rather from the water retained in the coating which is lost by vaporization during storage (KESTER; FENNEMA, 1986) masking the results. The films based on proteins and carbohydrates often provide a good barrier against oxygen and have good mechanical properties, but their barrier against water vapor is poor due to their hydrophilic nature (GENNADIOS et al., 1994).

Samples stored with polystyrene and polyethylene film showed minimized loss of mass, regardless of the processing levels. Certainly, this positive effect is attributed to the low permeability of these packages to water vapor combined with the effect of passive modified atmosphere and low temperature, which reduced respiratory activity. According to Kluge and Jorge (1992), the effect of the polyethylene film occurs by maintaining a high relative humidity around the fruit, which minimizes the water vapor pressure deficit and consequently prevents a significant fruit water loss due to transpiration. Pretel et al. (1998) and Pinto, Vilas Boas and Damiani (2007) found weight losses below $0.2 \%$ for 'Salustiana' citrus fruits peeled and stored in polyethylene film, and maximum loss of $0.3 \%$ for 'Ponkan' tangerines peeled and packed in polypropylene plastic container with a lid, respectively.

Weight loss of fruits packed in PVC was higher than that of fruits packed in polyethylene film (Figure 1). This fact is due to the lower thickness of this material $(9 \mu \mathrm{m})$, which leads
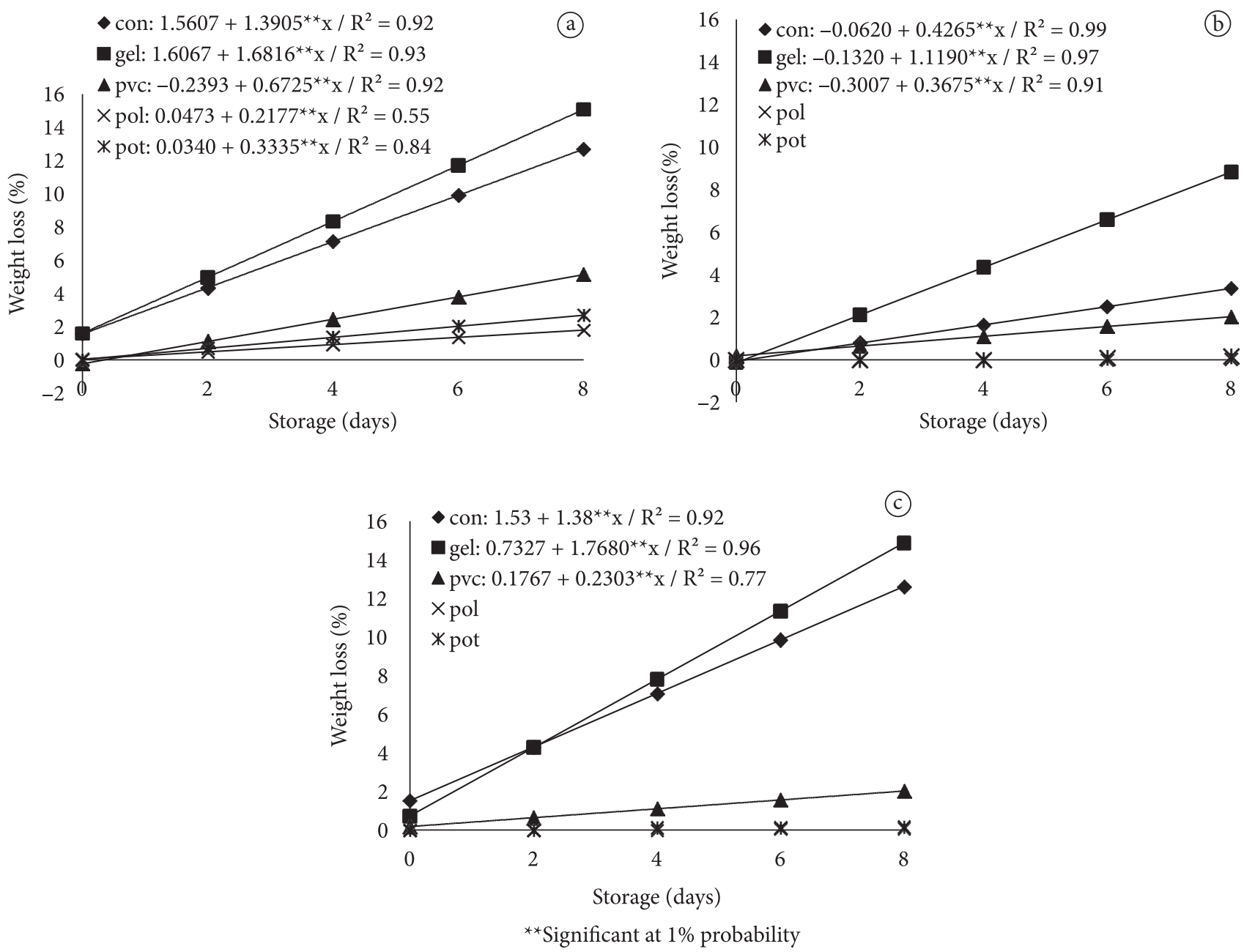

Figure 1. Weight loss versus storage time of 'Champagne' oranges stored in different packaging type (con: control; gel: $3 \%$ gelatin-based film, pvc: polyvinyl chloride film; pol: polyethylene film; pot: polystyrene container with lid) and processing: a) whole fruit without flavedo; b) whole fruit without flavedo and albedo; c) fruits segmented into wedges. 
to a thinner permeability barrier, thus allowing greater water exchange. Pretel et al. (1998) found that orange wedges stored in thin film barrier had the highest weight loss when compared to oranges wrapped with thicker film barrier.

Regardless of the type of the minimal processing operation, the fruits were submitted, it was demonstrated that the fruits packed in EPS with PVC, EPS with polyethylene, and polystyrene containers kept their overall fresh visual appearance and quality without signs of wilting up to the eighth day of storage at $5{ }^{\circ} \mathrm{C}$.

The weight loss of the whole fruit without flavedo was higher than the fruit without flavedo and albedo, which were up to $15.06 \%$ and $8.82 \%$, respectively. In this case, this is attributed to the higher weight loss of the spongy structure of the albedo, which is rich in pectin and hemicellulose (SIMÃO, 1998; MENDONÇA et al., 2006). Pectin is water soluble, and when it has a high content of Methoxyl groups, it exhibits a high gelling power with sugars and acids (UENOJO; PASTORE, 2007) connecting easily to water molecules, which will be lost during storage because of the differences in water vapor pressure between the air and the fruit tissue. Therefore, it is more likely that the water lost did not evaporate from the fruit juice.
Comparing the whole fruit without flavedo and albedo, with the fruits segmented into wedges, it was observed that the weight loss in the segmented fruits was higher. In both cases, the area which was exposed to air corresponded to the core material, rich in cellulose, but the weight loss in the fruit was higher when it was segmented due to the increased area of exposure.

Considering that weight losses in the order of 3-6\% are sufficient to cause a marked decline in the quality of the fruits (CHITARRA; CHITARRA, 2005), the control treatment and the fruits without flavedo, coated with gelatin-based film (3\%), or segmented showed poor visual quality after the $4^{\text {th }}$ day of storage; while the fruits without albedo and flavedo and coated with gelatin-based film showed poor visual quality after the $6^{\text {th }}$ day of storage.

With respect to TA, it was found that for all three types of processing, time factor significantly influenced the reduction of the TA as storage time progressed, but without significant influence on the type of packaging used (Figure 2). The fruits submitted to less drastic processing (whole fruit without flavedo) had the smallest reduction in citric acid content, $7.05 \%$, compared with values of $21.59 \%$ and $20.45 \%$ presented
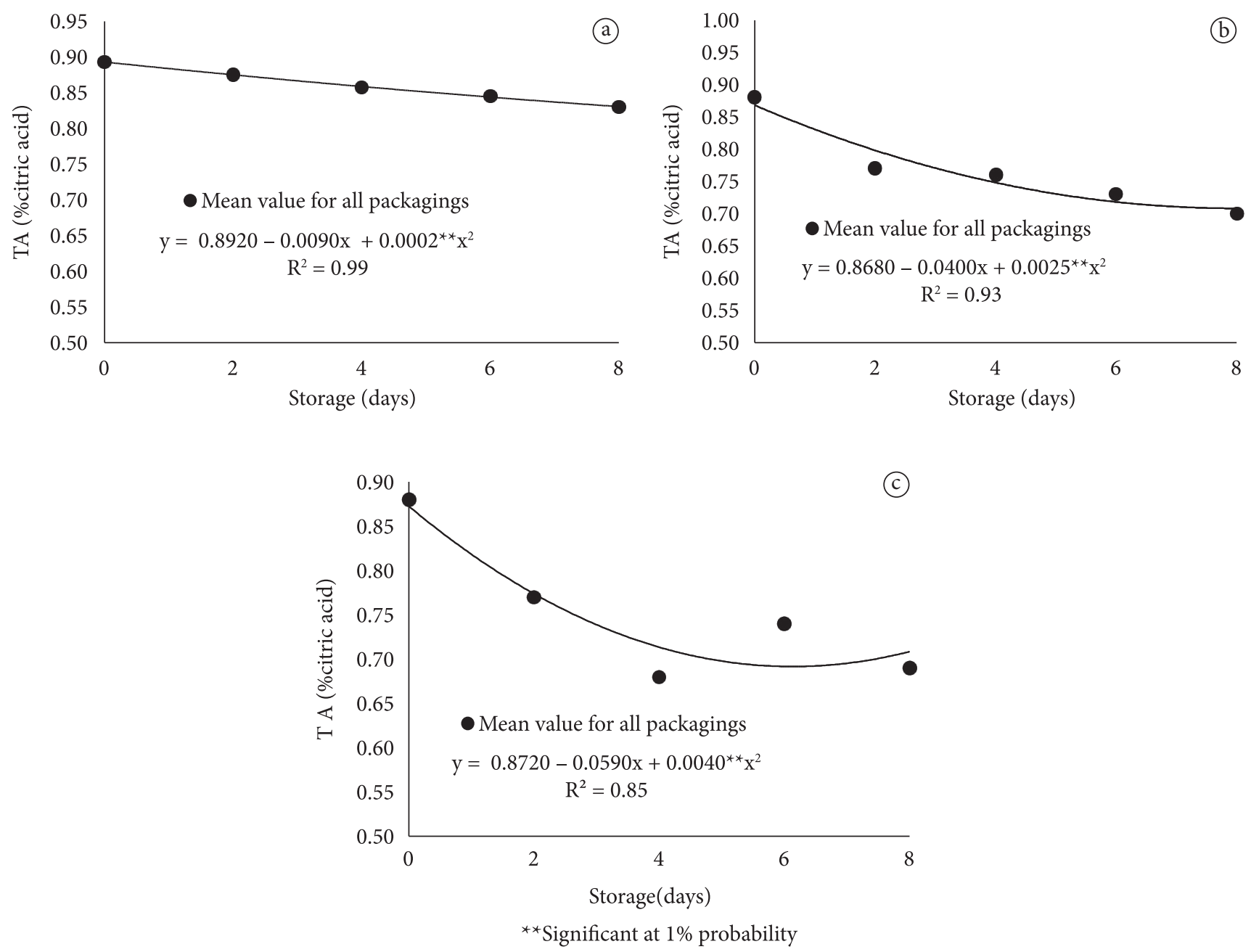

Figure 2. Titratable acidity (TA) versus storage time of 'Champagne' orange juice stored in different packaging type and processing: a) whole fruit without flavedo; b) whole fruit without flavedo and albedo; c) fruits segmented into wedges. 
by the whole fruits without flavedo and albedo and the fruits segmented, respectively.

This reduction may have occurred in response to injury to the fruit tissue during processing, which could lead to a series of complex biochemical and physiological responses (respiratory rate), resulting in a larger consumption of substrates such as organic acids. This reduction in the TA profile during storage, regardless of the treatment, was also observed by Leme et al. (2007) in "Pera" oranges and in oranges from Portugal by Rocha et al. (1995). On the other hand, some studies involving minimally processed citrus fruits reported no changes in the content of this parameter during the evaluation periods (ARRUDA et al., 2011; PRETEL et al., 1998; KLUGE et al., 2003; DONADON et al., 2004; GROPPO et al., 2009).

Parallel to decrease in the TA content, it was observed a little increase in $\mathrm{pH}$ over time (Figure 3), and for the fruit without flavedo, such increase started only after the $4^{\text {th }}$ day. Moreover, in the fruits without flavedo and segmented, there was significant influence of the packaging type. This increase in $\mathrm{pH}$ could be a result of the fruit tissue undergoing oxidative browning reactions (BAVERMAN, 1967 apud LEME et al., 2007).

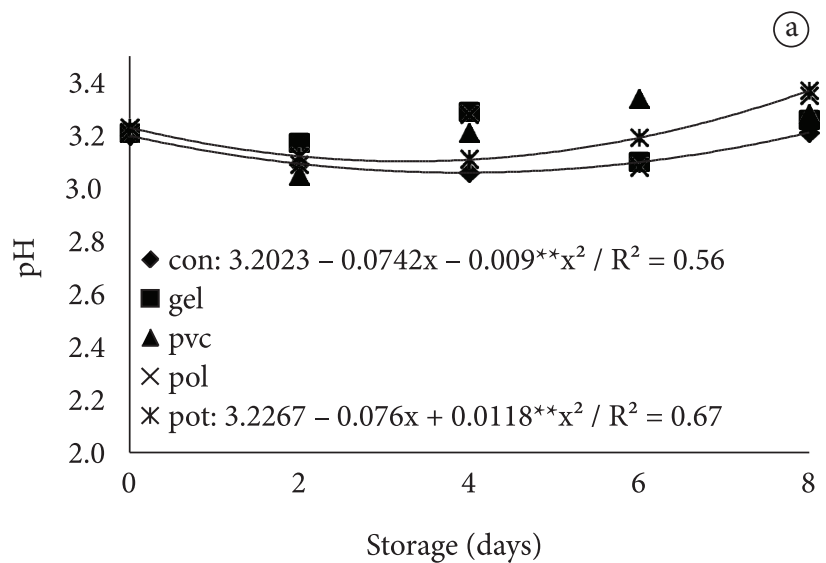

It has been shown by Tibola et al. (2006) that the $\mathrm{pH}$ of minimally processed 'Clemenules' and 'Marisol' tangerines decreased during storage, and the authors associated this behavior to the production of organic acids arising from biochemical changes during storage; which could also explain the results obtained in this study.

The levels of TSS and total sugars in the fruit juice of 'Champagne' oranges subjected to less drastic minimal processing (only removal of the flavedo) were not affected by packaging type and storage time, with values around $11.34 \%$ $(\mathrm{CV}=6,62 \%)$ and $9.46 \%(\mathrm{CV}=7.27)$, respectively. Therefore, these results are not shown in Figure 4. It is worth mentioning that although this kind of minimal processing resulted in greater mass loss, it did not influence the concentration of TSS and sugars since the loss was restricted to the albedo layer only. Many studies dealing with citrus stability have demonstrated TSS content as a function of time and treatments, even in those cases in which the fruits underwent more severe types of processing, such as the removal of the peel or segmentation (PRETEL et al., 1998; KLUGE et al., 2003; DONADON et al., 2004).

For the treatments in which the fruits were submitted to flavedo and albedo removal, the interaction between packaging

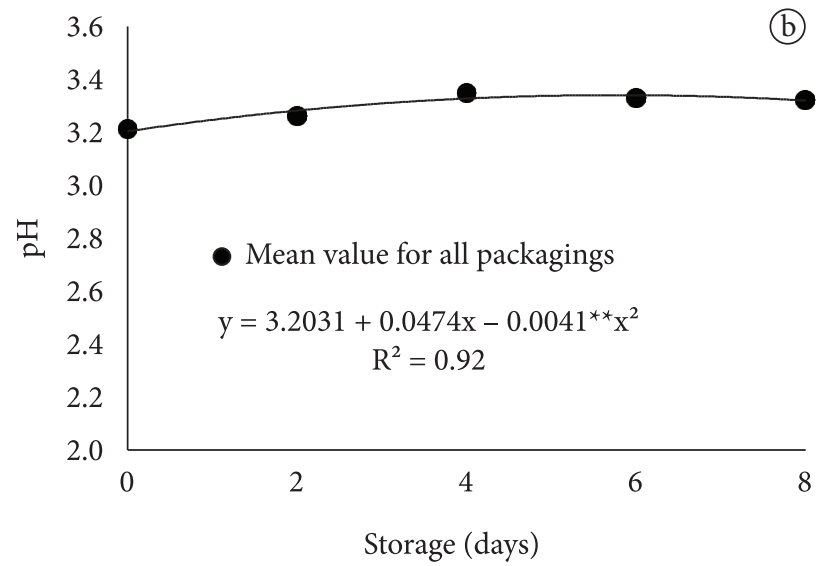

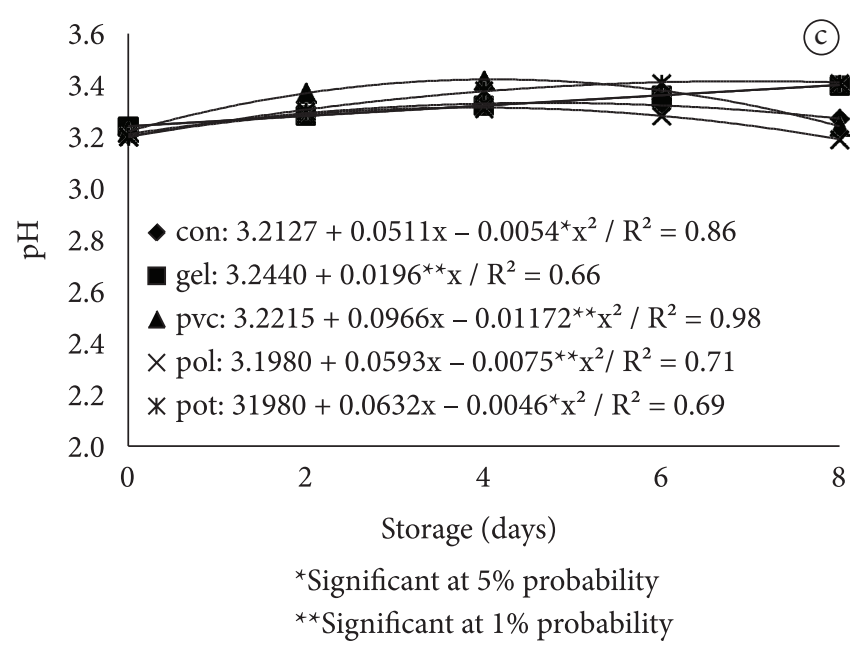

Figure 3. pH versus storage time of 'Champagne' orange juice stored in different packaging type (con: control; gel: 3\% gelatin-based film; pvc: polyvinyl chloride film; pol: polyethylene film; pot: polystyrene container with lid) and processing: a) whole fruit without flavedo; b) whole fruit without flavedo and albedo; c) fruits segmented into wedges. 
type and storage time significantly affected TSS content (Figure 4). For the fruits packed in polystyrene containers and polyethylene film, a slight tendency to reduction in TSS content at the end of storage was found. This response profile may indicate the consumption of these compounds by the respiratory process, which tends to increase after the processing of the fruits. Furthermore, these results are in agreement with those found for minimally processed 'Marisol' mandarin (TIBOLA et al., 2006), minimally processed 'Ponkan' mandarin (PINTO; VILAS BOAS; DAMIANI, 2007), minimally processed tangelo 'Minneola' (DEL CARO et al., 2004), and minimally processed 'Pera' orange (ARRUDA et al., 2011). Different behavior profile was observed for the uncoated fruits and those coated with gelatin-based film, in which there was little tendency to TSS increase during storage, which was justified by the greatest loss of moisture in these treatments, which led to concentrated TSS.

For sugars to glucose, a significant interaction between storage time and package type was found for fruits without flavedo and albedo (Figure 5), but the magnitude of these changes is small.

With regard to the treatment of fruits segmented into wedges, the storage time significantly influenced the content of their constituents, characterized mainly by an initial decrease followed by an increase up to the $6^{\text {th }}$ day of storage and another decrease. This initial decrease is attributed to intense breathing through which fruits are subjected during processing as soon as it is injured since sugars are necessary as substrate in the metabolic process. Correspondingly, there is a conversion

(a)
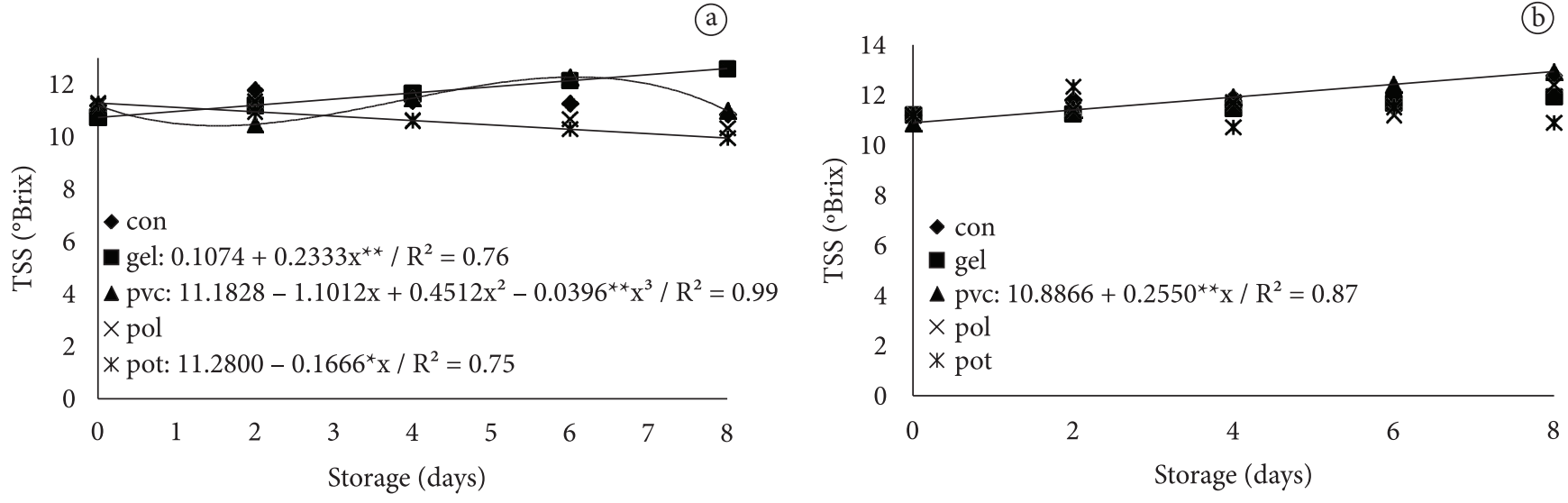

${ }^{*}$ Significant at $5 \%$ probability

${ }^{*}$ Significant at $1 \%$ probability

Figure 4. TSS versus storage time of 'Champagne' orange juice stored in different packaging type (con: control; gel: 3\% gelatin-based film; pvc: polyvinyl chloride film; pol: polyethylene film; pot: polystyrene container with lid) and processing: a) whole fruit without flavedo and albedo; b) fruits segmented into wedges.
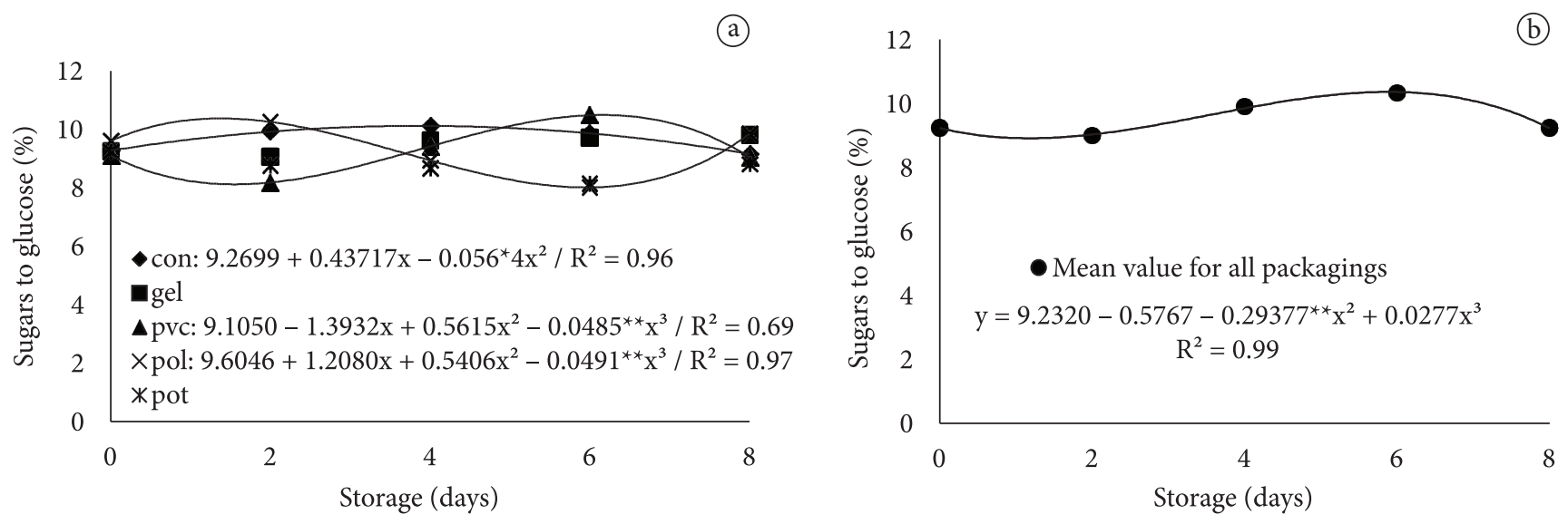

${ }^{\star}$ Significant at $5 \%$ probability

${ }^{*}$ Significant at $1 \%$ probability

Figure 5. Sugars (glucose) versus storage time of 'Champagne' orange juice stored in different packaging type (con: control; gel: 3\% gelatin-based film; pvc: polyvinyl chloride film; pol: polyethylene film; pot: polystyrene container with lid) and processing: a) whole fruit without flavedo and albedo; b) fruits segmented into wedges. 
of sucrose into reducing sugars, glucose and fructose, which could then be used in the metabolic processes (ROCHA et al., 1995). The subsequent increase up to the $6^{\text {th }}$ day may be due to additional production of these sugars by polysaccharide metabolism present in cell walls (FENNEMA, 1996) until they are no longer sufficient to produce sugars and their use in respiration results in new content reduction.

The content of ascorbic acid (AA) in minimally processed 'champagne' orange varied significantly only as a function of time for all types of processing tested, with no significant difference between the treatments (Figure 6). Del-Valle et al. (2009) and Iuamoto (2009) also observed this same behavior, and although the different types of modified atmosphere used did not differ significantly, the authors associated the greater loss of AA with higher concentrations of oxygen in the packaging.

In the present study, it was found that at first, the levels of AA tended to decrease on the $4^{\text {th }}$ or $6^{\text {th }}$ day of storage to the respective proportion of $8.42 \%, 9.46 \%$, and $14.48 \%$, for fruits without flavedo, flavedo and albedo, and segmented into wedges.

Losses in ascorbic acid content during storage of minimally processed citrus fruits ranging from $7.08 \%$ to $36 \%$ have been reported in other studies (ROCHA et al., 1995; DEL CARO et al.,
2004; TIBOLA et al., 2006; PINTO; VILAS BOAS; DAMIANI, 2007; PLAZA et al., 2011). These losses are related to degradation promoted by oxidative processes stimulated by the presence of light, oxygen, heat, and enzymes such as peroxides and ascorbate oxidase or peroxidase (PLAZA et al., 2006).

Based on these results, it is clear therefore that the packaging technology has not prevented the reduction of the levels of AA, and the losses were larger as the levels of operations increased. Tissue cuts result in an increase in the enzymatic activity promoting the loss of AA contents (CHITARRA, 2000).

With regard to the microbiological analysis, it was found that during storage, there was an increase in the counts of the psychrotrophic microorganisms, and the highest counts $\left(10^{5} \mathrm{CFU} \mathrm{g}^{-1}\right)$ were obtained for the segmented fruits and those coated with a gelatin-based film. Nevertheless, the counts did not exceed the acceptable limits of good quality foods (BRAZIL, 2001). The mixture of the proteinaceous film material and the juice exudated may have been used as a culture media promoting microbial growth with a consequent increase in microorganism counts.

ANVISA (BRASIL, 2001) has not established limits for the amount of yeasts and molds recommended in fruits and
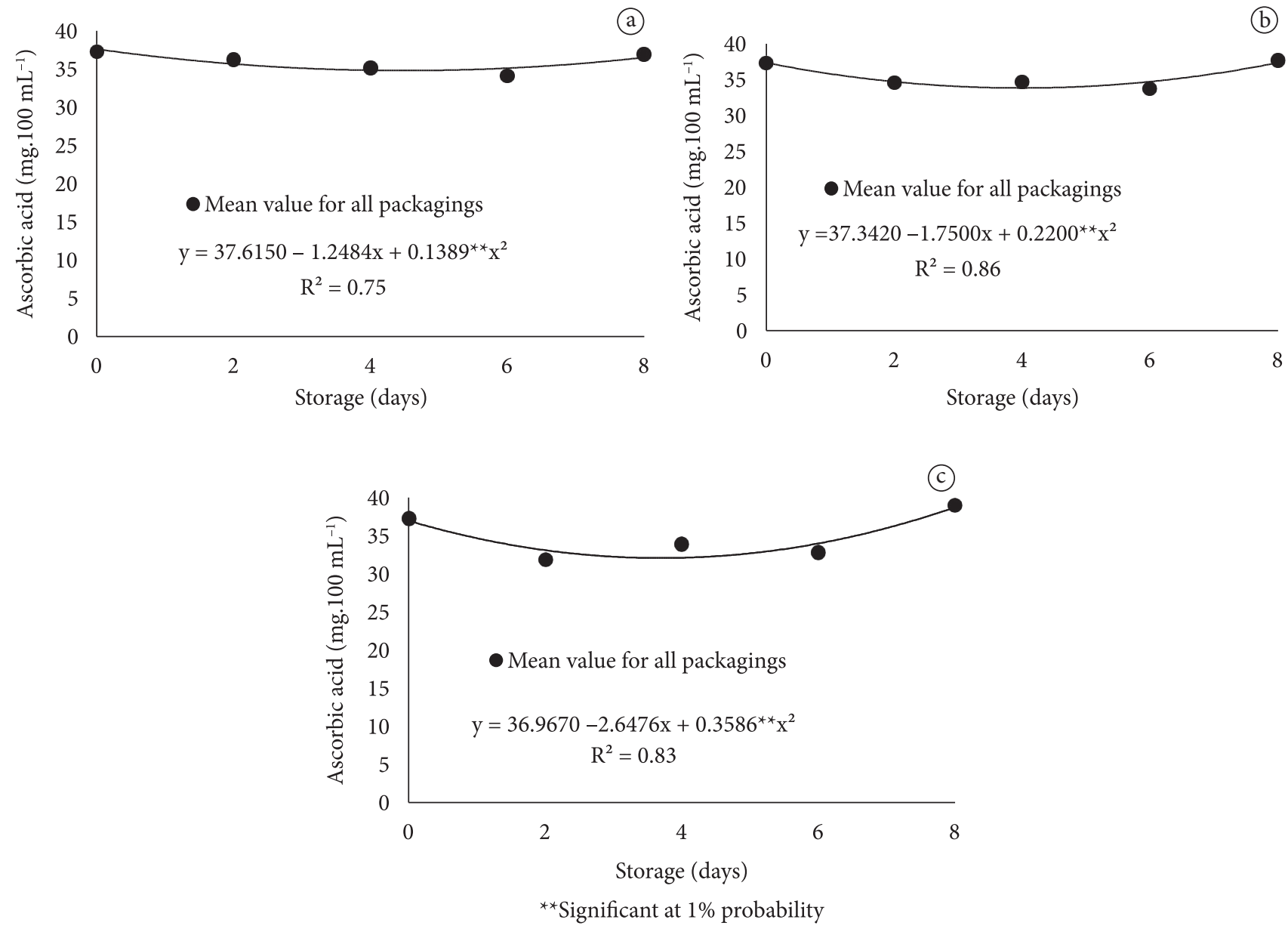

Figure 6. Ascorbic acid (AA) versus storage time of 'Champagne' orange juice stored in different packaging type and processing: a) whole fruit without flavedo; b) whole fruit without flavedo and albedo; c) fruits segmented into wedges. 
vegetables; however, foods containing high counts $\left(10^{4}\right.$ and $10^{5} \mathrm{CFU} \mathrm{g}^{-1}$ ) should be avoided. The total count of yeasts and molds obtained for the fruit samples in this study demonstrated that the fruits stored for longer periods tended to have the highest counts; however, no samples had counts greater than $10^{4} \mathrm{CFU} \mathrm{g}^{-1}$.

The minimally processed fruits containing albedo showed higher counts of these microbial agents although the opposite was expected because the albedo can serve as a mechanical barrier. In this case, although the albedo is an inhospitable environment for bacteria growth due to its low moisture content and presence of essential oils - since it is composed by cellulose which, in turns, is a source of carbohydrate - it is possible that it is used as a nutritional media for the proliferation of fungi.

The limits recommended by ANVISA (BRASIL, 2001) are $5 \times 10^{2} \mathrm{~g} \mathrm{NMP} / \mathrm{g}^{-1}$ of coliforms at $45^{\circ} \mathrm{C}$ for fresh fruits and vegetables. None of the treatments demonstrated the presence of fecal coliforms; however, the treatments in which the flavedo and albedo were removed or the fruits were segmented, uncoated and coated with $3 \%$ gelatin-based film showed higher counts of total coliforms, especially at the end of storage. It should be emphasized that the presence of coliforms indicates poor handling of food during processing, use of equipment in poor sanitary conditions, or use of contaminated raw material (INTERNATIONAL COMMISSION ON SPECIFICATIONS FOR FOODS MICROBIOLOGICAL - ICMSF, 1978).

Based on these results, it can be said that the use of good handling practices during minimal processing of fruits associated with favorable intrinsic characteristics of orange (low metabolism, low $\mathrm{pH}$, presence of essential oils, etc.) accounted for the microbiological counts acceptable limits.

\section{Conclusions}

The edible gelatin-based film (3\%) was not efficient in reducing the weight loss of 'champagne' oranges, while using the polyethylene and PVC films and the polystyrene container, weight loss were less than $5 \%$ after 8 days of storage at $8{ }^{\circ} \mathrm{C}$.

The fruits submitted to segmentation into wedges showed changes of greater magnitude compared to those of the fruits with lower levels of processing.

'Champagne' oranges packaged in PVC, polystyrene containers with lids, and polyethylene films, regardless of the level of processing submitted, kept a good appearance and showed a few changes in the physicochemical and microbiological characteristics which did not compromise their quality up to the $8^{\text {th }}$ day of storage.

\section{Acknowledgements}

The authors are grateful to the Federal University of Grande Dourados (UFGD) for the financial support provided and to the University Center of Grande Dourados (UNIGRAN) for enabling the use of its material, equipment, and facilities, which were indispensable in conducting this study.

\section{References}

ARAÚJO, F. M. M. C.; CHITARRA, A. B. Armazenamento de melão orange flesh minimamente processado sob atmosfera modificada. Ciência e Agrotecnologia, v. 29, n. 2, p. 346-352, 2005.

ARRUDA, M. C. et al. Hydrotermal treatment favors peeling of 'Pêra' sweet orange and does not alter quality. Scientia Agricola, v. 65 , p. 151-156, 2008. http://dx.doi.org/10.1590/S010390162008000200007

ARRUDA, M. C. et al. Atmosfera modificada em laranja 'Pêra' minimamente processada. Bragantia, v. 70, n. 3, p. 664-671, 2011. http://dx.doi.org/10.1590/S0006-87052011000300023

ARTÉS-HERNÁNDEZ, F.; RIVERA-CABRERA, F; KADER, A. A. Quality retention and potential shelf-life of fresh-cut lemons as affected by cut type and temperature. Postharvest Biology and Technology, v. 43, p. 245-254, 2007. http://dx.doi.org/10.1016/j. postharvbio.2006.09.009

ASSOCIATION OF OFFICIAL ANALYTICAL CHEMISTS - AOAC. Official methods of analysis of the AOAC.Washington, 1997. v. 2, p. 16-17. PMCid:2723325.

BRASIL. Agência Nacional de Vigilância Sanitária. Resolução RDC $\mathrm{n}^{\circ} 12$ de 02 de janeiro de 2001. Dispõe sobre o Regulamento técnico sobre padrões microbiológicos para alimentos. Diário Oficial da República Federativa do Brasil, Brasília, DF, 10 jan. 2001.

CHITARrA, M. I. F.; CHITARRA, A. B. Pós-colheita de frutas e hortaliças: fisiologia e manuseio. 2. ed. Lavras: ESALI FAEPE, 2005. 783 p.

CHITARRA, M. I. F. Processamento mínimo de frutos e hortaliças. Lavras: UFLA/FAEPE, 2000. 113 p.

DEL CARO, A. et al. Changes of flavonoids, vitamin C and antioxidant capacity in minimally processed citrus segments and juices during storage. Food Chemistry, v. 84, p. 99-105, 2004. http://dx.doi. org/10.1016/S0308-8146(03)00180-8

DEL-VALLE, V. et al. Optimization of an equilibrium modified atmosphere packaging (EMAP) for minimally processed mandarin segments. Journal of Food Engineering, v. 91, p. 474-481, 2009. http://dx.doi.org/10.1016/j.jfoodeng.2008.09.027

DONADON, J. R. et al. Efeito do tipo de descasque e da temperatura de armazenamento na qualidade de laranjas "Pera" minimante processadas. Revista Brasileira de Fruticultura, v. 26, n. 3, p. 419423, 2004. http://dx.doi.org/10.1590/S0100-29452004000300012

FENNEMA, O. R. Food Chemistry. 3. ed. New York: Marcel Dekker, 1996.

GENNADIOS, A. et al. Edible coatings and films based on proteins. In: KROCHTA, J. M. et al. (Eds.). Edible coatings and films to improve food quality. Lancaster: Technomic Publishing Company, 1994. cap. 9, p. 201-277.

GROPPO, V. D. et al. Efeito do cloreto de cálcio e da película de alginato de sódio na conservação de laranja 'Pera' minimamente processada. Ciência e Tecnologia de Alimentos, v. 29, n. 1, p. 107-113, 2009. http://dx.doi.org/10.1590/S0101-20612009000100017

INSTITUTO ADOLFO LUTZ - IAL. Métodos físico-químicos para análise de alimentos. 4. ed. Brasília: ANVISA, 2005. 1018 p.

IUAMOTO, M. Y. Processamento mínimo de laranja 'Pera': tipo de corte, sanitização, centrifugação e atmosfera modificada. 2009. 63 f. Dissertação (Mestrado em Ciências)-Universidade de São Paulo, Piracicaba, 2009.

JACOMINO, A. P.; ARRUDA, M. C.; MOREIRA, R. C. Tecnología de processamento mínimo de frutas cítricas. In: SIMPOSIUM "NUEVAS TECNOLOGÍAS DE CONSERVACIÓN Y ENVASADO 
DE FRUTAS Y HORTALIZAS. VEGETALES FRESCOS CORTADOS”, 2005, La Habana, Cuba. Anales... La Habana, 2005.

KADER, A. A. et al. Modified atmosphere packaging of fruits and vegetables. Critical Reviews in Food Science and Nutrition, v. 28, n. 1, p. 1-30, 1989. PMid:2647417. http://dx.doi. org/10.1080/10408398909527490

KESTER, J. J.; FENNEMA, O. Edible films and coatings: a review. Food technology, v. 40, v. 12, p. 47-59, 1986.

KLUGE, R. A. et al. Temperatura de armazenamento de tangores 'Murcote' minimamente processados. Revista Brasileira de Fruticultura, v. 25, n. 3, p. 535-536, 2003. http://dx.doi.org/10.1590/ S0100-29452003000300044

KLUGE, R. A.; JORGE, R. Efeito da embalagem de polietileno na frigoconservação de ameixas amarelinhas. Revista Brasileira de Fruticultura, v. 231, n. 3, p. 21-25, 1992.

LEME, A. C. et al. Influência do uso de películas comestíveis em laranja 'Pêra' minimamente processada. Boletim do CEPPA, v. 25, n. 1, p. 15-24, 2007.

LIMA, Á. S. et al. Adição de agentes antiescurecimento, antimicrobiano e utilização de diferentes filmes plásticos, em mamão minimamente processado. Revista Brasileira de Fruticultura, v. 27 , n. 1, p. 149-152, 2005. http://dx.doi.org/10.1590/S010029452005000100039

MENDONÇA, L. M. V. L. et al. Caracterização da composição química e do rendimento dos resíduos industriais do limão Tahiti (Citrus latifolia Tanaka). Ciência e Tecnologia de Alimentos, v. 26 , n. 4 , p. $870-874$, 2006. http://dx.doi.org/10.1590/S010120612006000400025

NEGUYEN-THE, C.; CARLIN, F. The microbiology of minimally processed fresh fruits and vegetables. Critical Reviews in Food
Science and Nutrition, v. 34, n. 4, p. 371-401, 1994. http://dx.doi. org/10.1080/10408399409527668

PLAZA, L. et al. Impact of minimal processing on orange bioactive compounds during refrigerated storage. Food Chemistry, v. 124, p. 646-651, 2011. http://dx.doi.org/10.1016/j.foodchem.2010.06.089

PLAZA, L. et al. Effect of refrigerated storage on vitamin C and antioxidant activity of orange juice processed by high-pressure or pulsed electric fields with regard to low pasteurization. European Food Research and Technology, v. 223, n. 4, p. 487-493, 2006. http://dx.doi.org/10.1007/s00217-005-0228-2

PINTO, D. M.; VILAS BOAS, E. V. B.; DAMIANI, C. Qualidade de tangerina Poncã minimamente processada armazenada a $5{ }^{\circ} \mathrm{C}$. Ciência e Agrotecnologia, v. 31, n. 4, p. 1131-1135, 2007. http:// dx.doi.org/10.1590/S1413-70542007000400028

PRETEL, M. T. et al. The Effect of Modified Atmosphere Packaging on 'Ready-to-Eat' Oranges. Lebensmittel-Wissenschaft und Technologie, v. 31, p. 322-328, 1998.

ROCHA, A. M. C. N. et al. Shelf-life of chilled cut orange determined by sensory quality. Food Control, v. 6, n. 6, p. 317-322, 1995. http:// dx.doi.org/10.1016/0956-7135(95)00019-4

SILVA, N. et al. Manual de métodos de análise microbiológica de alimentos. 3. ed. São Paulo: Livraria Varela, 2007. 536 p.

SIMÃO, S. Tratado de Fruticultura. Piracicaba: FEALQ, 1998. p. 419-465.

TIBOLA, C. S. et al. Qualidade e conservação de tangerina minimamente processada. Acta Scientiarium Agronomy, v. 28, n. 2, p. 193-197, 2006.

UENOJO, M.; PASTORE, G. M. Pectinases: aplicações industriais e perspectivas. Química Nova, v. 30, p. 388-394, 2007. http://dx.doi. org/10.1590/S0100-40422007000200028 